Article

\title{
Evaluation of Passive Samplers as a Monitoring Tool for Early Warning of Dinophysis Toxins in Shellfish
}

\author{
Gemita Pizarro ${ }^{1, \dagger}$, Ángeles Moroño ${ }^{2}$, Beatriz Paz ${ }^{1}$, José M. Franco ${ }^{3}$, Yolanda Pazos ${ }^{2}$ and \\ Beatriz Reguera ${ }^{1, *}$
}

1 Spanish Institute of Oceanography (IEO), Oceanographic Centre of Vigo, Subida a Radio Faro 50, Vigo 36390, Spain; E-Mails: gemita.pizarro@ifop.cl (G.P.); beapaz@uvigo.es (B.P.)

2 Technological Institute for the Control of the Marine Environment of Galicia (INTECMAR), Peirao de Vilaxoán s/n, Vilagarcía de Arousa, Pontevedra 36611, Spain;

E-Mails: amorono@intecmar.org (Á.M.); ypazos@intecmar.org (Y.P.)

3 Institute of Marine Research (CSIC), Eduardo Cabello 6, Vigo 36080, Spain;

E-Mail: jose.franco@vi.ieo.es

$\dagger$ Permanent address: Fisheries Institute (IFOP) and Centre for the Study of the Quaternary, Enrique Abelló 0552, Punta Arenas 6200000, Chile.

* Author to whom correspondence should be addressed; E-Mail: beatriz.reguera@vi.ieo.es; Tel.: +34-986-492-111; Fax: +34-986-498-626.

Received: 10 July 2013; in revised form: 19 August 2013 / Accepted: 23 August 2013 /

Published: 11 October 2013

Abstract: From June 2006 to January 2007 passive samplers (solid phase adsorbing toxin
tracking, SPATT) were tested as a monitoring tool with weekly monitoring of
phytoplankton and toxin content (liquid chromatography-mass spectrometry, LC-MS) in
picked cells of Dinophysis and plankton concentrates. Successive blooms of Dinophysis
acuminata, D. acuta and D. caudata in 2006 caused a long mussel harvesting closure
(4.5 months) in the Galician Rías (NW Spain) and a record (up to $9246 \mathrm{ng}$. $\mathrm{g}$ resin-week ${ }^{-1}$ )
accumulation of toxins in SPATT discs. Best fit of a toxin accumulation model was
between toxin accumulation in SPATT and the product of cell densities by a constant
value, for each species of Dinophysis, of toxin content (average) in picked cells. Detection
of Dinophysis populations provided earlier warning of oncoming diarrhetic shellfish
poisoning (DSP) outbreaks than the SPATT, which at times overestimated the expected
toxin levels in shellfish because: (i) SPATT accumulated toxins did not include
biotransformation and depuration loss terms and (ii) accumulation of toxins not available to
mussels continued for weeks after Dinophysis cells were undetectable and mussels were 
toxin-free. SPATT may be a valuable environmental monitoring and research tool for toxin dynamics, in particular in areas with no aquaculture, but does not provide a practical gain for early warning of DSP outbreaks.

Keywords: Dinophysis; early warning DSP outbreaks; HAB monitoring; modeling toxin accumulation; Solid Phase Adsorbing Toxin Tracking (SPATT); Galician Rías

\section{Introduction}

Dinoflagellate species of the genus Dinophysis have two kinds of lipophilic shellfish toxins (LST): diarrhetic shellfish poisoning (DSP) toxins_okadaic acid (OA) and dinophysistoxins (DTXs) — and pectenotoxins (PTXs) [1]. A few hundred cells of Dinophysis per liter, difficult to monitor due to their very patchy distribution, may lead to accumulation of toxins in shellfish [2-4] above regulatory levels established by the European Union [5] and lead to lengthy shellfish harvesting closures. The chronic detection of lipophilic shellfish toxins (OA, DTXs, PTXs) above regulatory levels in shellfish is a major threat to shellfish resources in Atlantic coastal waters of Europe [6]. To date, 12 species of Dinophysis have been found to contain lipophilic toxins, and blooms of seven of these have been associated with toxic outbreaks [7]. Large differences in toxin profile and content have been found between strains of the same species from different locations [6,8]. Further, the toxin per cell of the same species in the same location may vary up to one order of magnitude throughout its growing season [9]. For all these reasons, the use of "trigger levels" of Dinophysis cells as a monitoring practice to start shellfish analyses or even to ban bivalve harvesting cannot be recommended $[4,6,10]$.

MacKenzie et al. [11] introduced the use of passive samplers as a tool for early detection of toxins in aquaculture sites; these are made of porous synthetic resins able to adsorb lipophilic substances, including lipophilic shellfish toxins (LST). These authors claimed that during proliferations of Dinophysis in New Zealand coastal waters, an important proportion of their toxins were released into the seawater; they suggested that "solid phase adsorption toxin tracking" (SPATT) mesh bags filled with the porous resins (SPATT discs herein) could be used as an early warning tool in toxin monitoring programmes. SPATT discs have been tested at different shellfish growing sites in Europe, but for brief periods of time, and their performance has been compared with that of an artificial mussel, with the advantage that toxin extraction from the resins is easier and avoids interferences in chromatographic analyses due to complex matrices found in shellfish meat extracts [9,12-14].

During 2006, SPATT discs were deployed at different depths in the water column next to a mussel cultivation raft and renewed at weekly intervals during the whole growing season of Dinophysis spp. The study was carried out at a fixed station in Ría de Pontevedra, one of the four Galician Rías Baixas (NW Spain), site of intensive mussel production (Figure 1). This region suffers from chronic blooms of several species of Dinophysis, and DSP outbreaks lead to lengthy shellfish harvesting closures every year. The objective of this work was to evaluate the use of in situ deployed SPATT discs as a tool for (i) early detection of Dinophysis and its toxins in aquaculture sites with established molluscan shellfish safety monitoring programs; (ii) studying the in situ toxin dynamics associated with Dinophysis blooms. 
Figure 1. (a) The Galician Rías Baixas (b) The study area and location of the P2 station in Ría de Pontevedra.

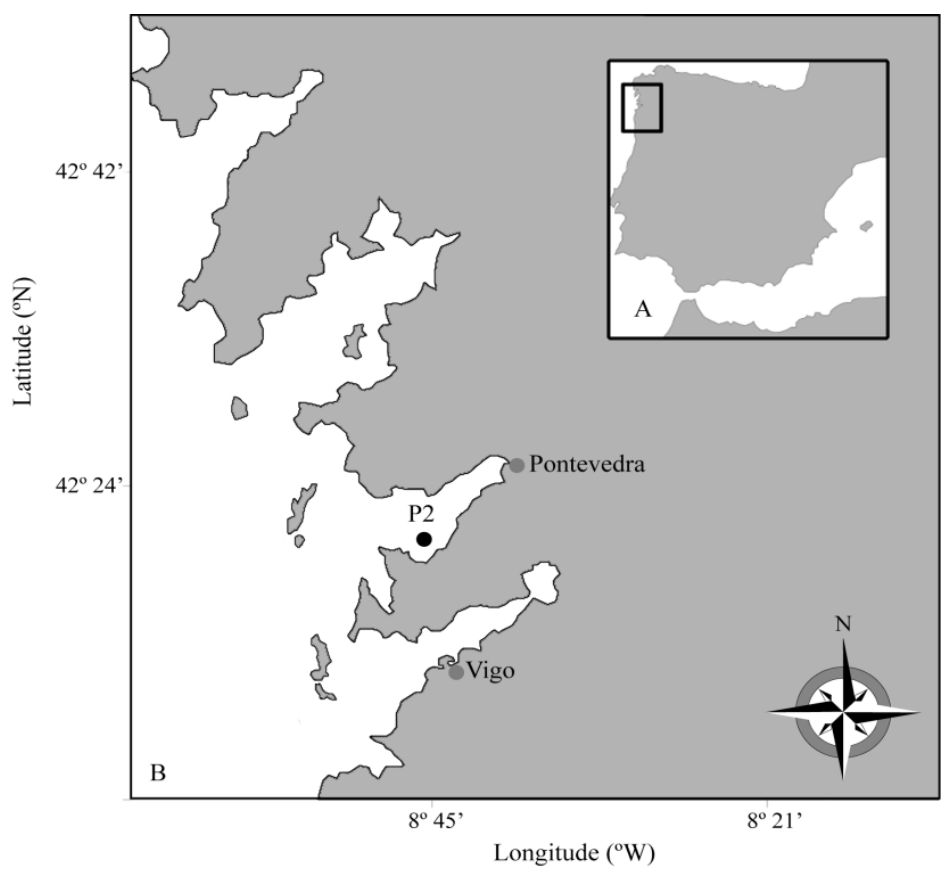

\section{Results}

\subsection{Seasonal Distribution of Dinophysis Species}

Weekly monitoring estimates from integrated water column samples $(0-5,5-10,10-15,15-20 \mathrm{~m})$ showed that in summer-autumn 2006, the first short-lived Dinophysis peak of the season (co-occurring with D. acuminata) on 12 June corresponded to a "Dinophysis sp." later identified as D. ovum [15]. From then until late August, D. acuminata, with cell maxima most times at $0-5 \mathrm{~m}$, was the overwhelmingly dominant species of Dinophysis. From 28 August to 24 October D. acuta became dominant while $D$. acuminata densities progressively declined. $D$. caudata densities started to increase on 25 September and its cell maxima co-occurred with those of D. acuta until the end of October. Both D. acuta and D. caudata showed a more even distribution in the $0-15 \mathrm{~m}$ water column, and their cell maxima appeared most times at 5-10 $\mathrm{m}$ and 10-15 $\mathrm{m}$. Finally by mid-November a sudden mono-specific peak of $D$. caudata was observed at $0-5 \mathrm{~m}$ (Figure 2).

\subsection{Dinophysis spp. in the Concentrated (Pump) Phytoplankton Samples}

Distribution of Dinophysis species in the pump concentrates showed a similar succession to that observed on the 0-5 $\mathrm{m}$ section of the integrated water column samples. An exception was the occurrence and dominance of D. ovum, which was practically the only species of Dinophysis in the size-fractioned $(77-20 \mu \mathrm{m})$ plankton concentrate on 12 June and the dominant species of Dinophysis until 26 July. In contrast D. acuminata was reported as the dominant species in the $0-5 \mathrm{~m}$ hose-samples from 17 July to mid-September. D. rotundata (=Phalacroma rotundatum) was also present (not included in the figure) representing a very small percentage of the total community of Dinophysis species (Figure 3a). 
Figure 2. Weekly distribution of Dinophysis species from depth integrated water column samples, at 0-5 m, 5-10 m, 10-15 m and 15-20 m, collected at the P2 station in Ría de Pontevedra.
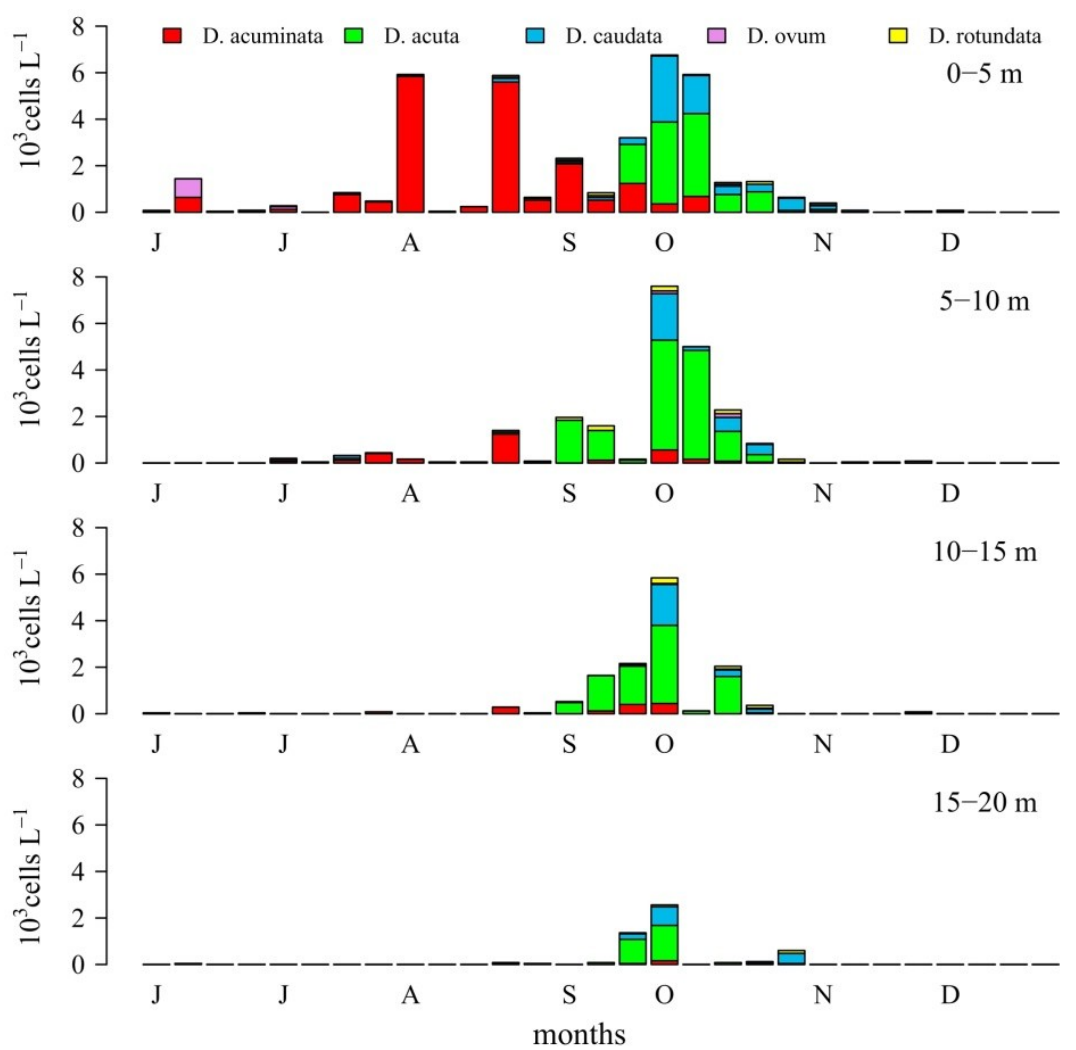

\subsection{Toxin Profile and Content in Picked Cells of Dinophysis from the Pump Concentrates}

Okadaic acid (OA) was the only toxin detected in picked cells of D. ovum (1.4-7.0 pg cell $\left.{ }^{-1}\right)$ and D. acuminata (1.7-6.6 $\mathrm{pg}^{-1} \mathrm{cel}^{-1}$ ) (Figure 3b). D. acuta was the species with the highest toxin content per cell. Its toxin profile was always dominated by OA $\left(0.9-8.4 \mathrm{pg}^{\text {cell }}{ }^{-1}\right)$, followed by DTX2 $\left(0.4-5.6 \mathrm{pg} \mathrm{cell}^{-1}\right)$ and PTX2 (1.0-6.1 $\left.\mathrm{pg} \mathrm{cell}^{-1}\right)$. D. caudata showed a more variable profile: PTX2 (0.6-5.5 pg cell $\left.{ }^{-1}\right)$ was the dominant toxin or even the only toxin present in some samples; OA (nd-4.8 pg cell ${ }^{-1}$ ) was detected in three out of nine samples and traces of DTX2 $\left(0.9 \mathrm{pg} \mathrm{cell}^{-1}\right)$ in only one sample where OA and DTX2 were predominant.

\subsection{Toxin Profiles and Content per Cell of Dinophysis in the Size-Fractioned Plankton Concentrates}

OA, DTX2 and PTX2 were the predominant toxins in the size-fractioned $(77-20 \mu \mathrm{m})$ phytoplankton pump-concentrates (Figure 3c). OA was the predominant toxin in concentrates rich in D. ovum and D. acuminata between 12 June and 7 August. After this period and until 18 September, the predominance of OA was associated with D. acuminata. The presence of PTX2 within this same period (3 July-18 September), and traces of DTX2 on 1 August corresponded to the occurrence of moderate densities of D. caudata. From 25 September to 30 October OA, followed by PTX2 and DTX2 were the predominant toxins in the D. acuta-dominated plankton concentrates. The PTX2 increase observed in the toxin profiles on 30 October co-occurred with a new increase of $D$. caudata. 
Figure 3. Dinophysis species from pump concentrates collected at station P2 (Ría de Pontevedra), between June and December 2006, at a fixed depth in the top $5 \mathrm{~m}$ (a) Distribution of cell densities of different species of Dinophysis; (b) Estimates of toxin content (pg cell ${ }^{-1}$ ) in single-cell isolates (picked cells) (c) Estimates of average toxin content (pg cell ${ }^{-1}$ ) per cell of Dinophysis in pump concentrates.
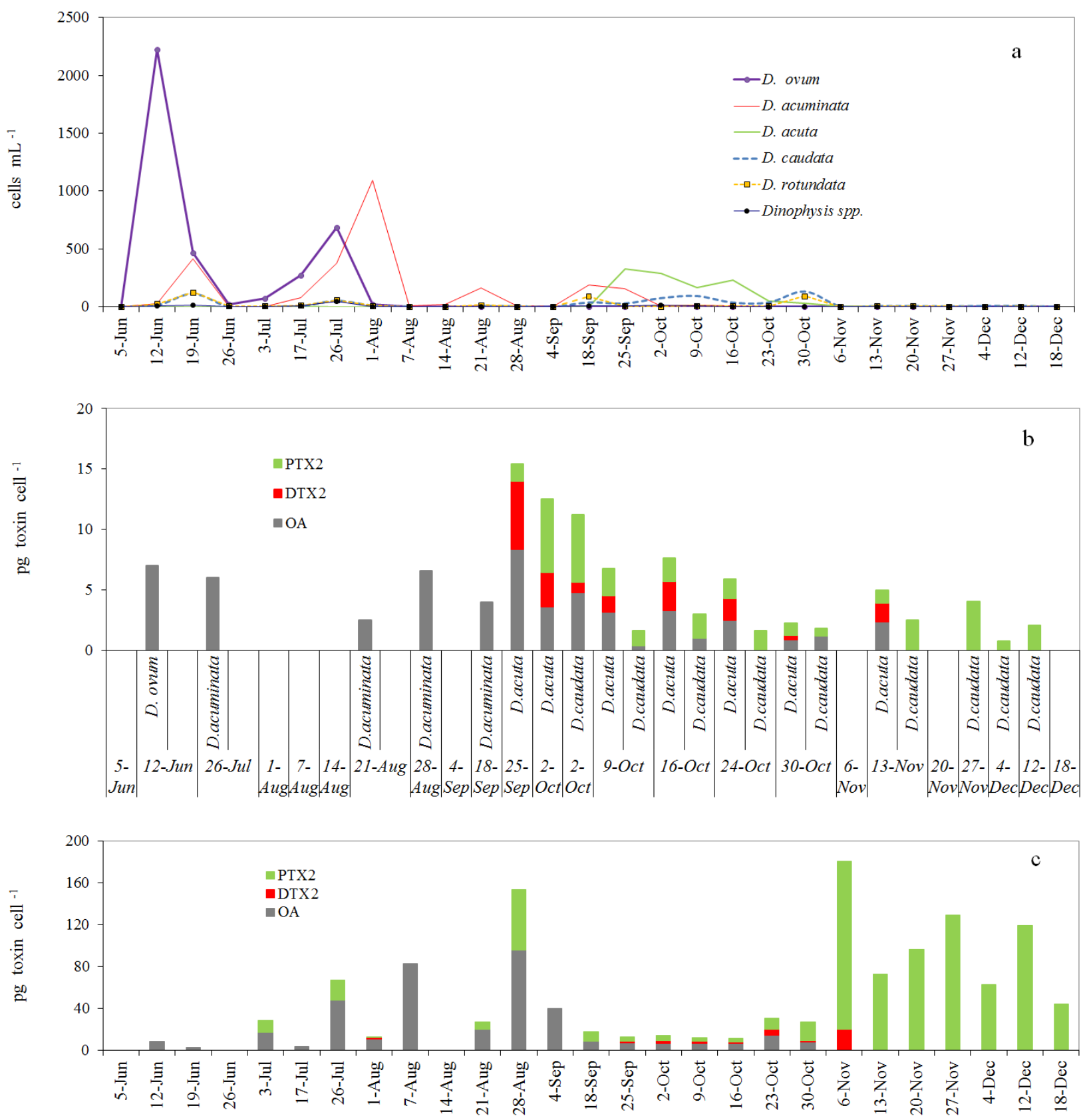

After 6 November and until 18 December PTX2 was the only toxin detected in the plankton concentrates when Dinophysis dropped to densities $\left(<9\right.$ cells $\left.\mathrm{mL}^{-1}\right)$ close to detection levels.

Estimates of toxin per cell from pump concentrates were often much higher (even an order of magnitude) than those obtained from picked cells. Thus, maximum values of $80.4 \mathrm{pg} \mathrm{OA} \mathrm{cell}^{-1}$ were observed during the bloom of $D$. acuminata by the end of August and of 161 pg PTX2 cell ${ }^{-1}$ by the end of the bloom of $D$. acuta plus $D$. caudata in early November. 


\subsection{Weekly Adsorption of Toxins in the SPATT Discs and Its Relation with Dinophysis Populations}

Weekly adsorption of toxins in the SPATT discs included those detected in picked cells of Dinophysis and in the plankton concentrates-OA, DTX2, PTX2-plus PTXSA, a toxin known to result from enzymatic transformation of PTX2 [16,17] (Figure 4).

\subsubsection{SPATT at $3 \mathrm{~m}$ versus Dinophysis Cells at $0-5 \mathrm{~m}$}

OA adsorbed by the SPATT discs deployed at $3 \mathrm{~m}$ ranged between 66 and $4495 \mathrm{ng} \cdot \mathrm{g}$ resin-week ${ }^{-1}$. There was a lag of 2 weeks between the first peaks $\left(>10^{3}\right.$ cells $\left.\cdot \mathrm{L}^{-1}\right)$ of $D$. ovum + D. acuminata (12 June) and the first detection of OA (26 June) by the SPATT discs (Figure 4a). The highest adsorption (4495 $\mathrm{ng} \cdot \mathrm{g}$ resin-week ${ }^{-1}$ ) on 28 August was observed following the seasonal maximum of D. acuminata $\left(10^{4}\right.$ cell $\left.\cdot \mathrm{L}^{-1}\right)$ the previous week. New high levels of OA (up to $3640 \mathrm{ng} \cdot \mathrm{g}$ resin-week ${ }^{-1}$ ) were observed between 28 August and 10 October when D. acuta and D. acuminata co-occurred. After mid October concentrations gradually declined ( $<200 \mathrm{ng} \cdot \mathrm{g}$ resin-week $\left.{ }^{-1}\right)$ until the end of the study. High densities of D. acuta on 2-9 October with a moderate toxin per cell did not contribute to substantial accumulation of OA the following days.

DTX2 accumulated by the SPATT discs ranged between 30 and $1876 \mathrm{ng} \cdot \mathrm{g}$ resin-week ${ }^{-1}$. There was a lag of 21 days between the onset of the D. acuta bloom (28 August) and the adsorption of DTX2 by the SPATT (18 September). The highest accumulation (1876 $\mathrm{ng} \cdot \mathrm{g}$ resin $\cdot \mathrm{week}^{-1}$ ) on 9 October followed the peaks of $D$. acuta and D. caudata the previous week, although DTX2 content in the former species was threefold that of the latter (Figure 3b), so the contribution of D. caudata may not have been significant. After 9 October, DTX2 was no longer detected in picked cells of $D$. caudata cells, so this toxin was contributed only by the population of D. acuta. DTX2 was still found in the SPATT discs 7 days after D. acuta was no longer detected.

PTX2 adsorption ranged between 40 and $2705 \mathrm{ng} \cdot \mathrm{g}$ resin-week ${ }^{-1}$. This toxin was first found on 1 August, i.e., 15 days after detection of 80 cells $\cdot \mathrm{L}^{-1}$ of $D$. caudata at $10-15 \mathrm{~m}$. PTX2 was first detected in the phytoplankton pump-concentrates on 23 and 26 of July, and was tracked by the SPATT discs at $3 \mathrm{~m}$ until the end of the study, almost 2 months after Dinophysis species were below detection levels.

Concentrations of PTX2SA ( 37 to $845 \mathrm{ng} \cdot \mathrm{g}$ resin-week ${ }^{-1}$ ), a toxin that was never detected either in picked cells of Dinophysis or in the pump concentrates, was significantly related $\left(r^{2}=0.78, p<0.001\right)$ with those of PTX2 at the same depth.

\subsubsection{SPATT Discs at $7 \mathrm{~m}$ versus Dinophysis Cells at 5-10 $\mathrm{m}$}

The ranges of OA, DTX2, PTX2 and PTXSA adsorbed by the SPATT discs at $7 \mathrm{~m}$ were 22-4053, 30-1264, 19-1690 and 72-1072 ng.g resin-week ${ }^{-1}$, respectively (Figure 4b).

OA was first tracked by the SPATT discs on 5 and 19 June when D. acuta had not yet been detected and very low densities of D. acuminata and D. caudata were found in this layer of the water column. As in the $3 \mathrm{~m}$ SPATT, OA was tracked until the end of the study period. 
Figure 4. Distribution of Dinophysis (integrated water column) and weekly adsorption of toxins by the SPATT discs (ng toxin.g resin $\cdot w^{-1} \mathrm{k}^{-1}$ ) (a) Dinophysis at 0-5 $\mathrm{m}$ and SPATT discs at $3 \mathrm{~m}$ (b) Dinophysis at 5-10 $\mathrm{m}$ and SPATT discs at $7 \mathrm{~m}$ (c) Dinophysis at 10-15 $\mathrm{m}$ and SPATT discs at $12 \mathrm{~m}$.
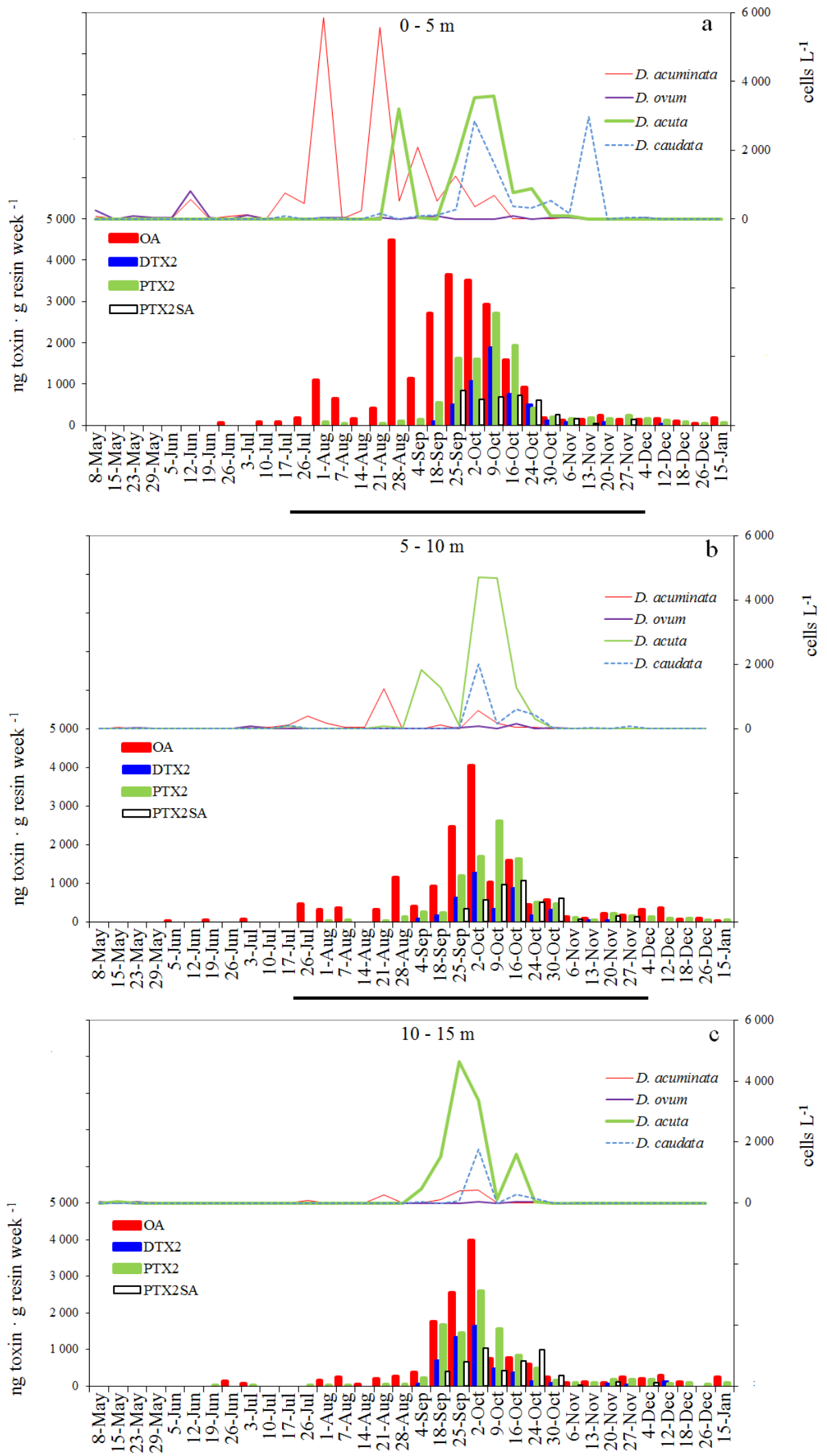

mussel harvesting closure 
DTX2 was not detected in the SPATT discs either when a slight increase of D. acuta and D. caudata was observed on 17 July or when there was a new increase of D. acuta on 21 August. Maximal concentrations (up to $1264 \mathrm{ng} \cdot \mathrm{g}$ resin-week ${ }^{-1}$ ) on 2 and 16 October were found just before and after the seasonal maxima of D. acuta. DTX2 were last detected at this depth on 24 October, i.e., $21 \mathrm{~d}$ after $D$. acuta was no longer detected in the plankton samples.

PTX2 was detected 15 days after the increase of D. acuta and D. caudata densities on 17 July. After this date, both species went undetected, but the SPATT discs continued tracking PTX2. D. acuta reappeared on 21 August and lasted until 24 October, and D. caudata was detected again on 2 October and dropped to undetectable levels on 27 November. However PTX2 was still present in the SPATT discs nearly 2 months later.

As in the $3 \mathrm{~m}$ SPATT discs, PTX2SA was significantly related $\left(r^{2}=0.80, p<0.001\right)$ with the concentrations of PTX2 adsorbed at the same depth.

\subsubsection{SPATT Discs at $12 \mathrm{~m}$ versus Dinophysis Cells at 10-15 m}

OA (49-3994 ng.g resin-week ${ }^{-1}$ ) was tracked on 26 June and 3 July when Dinophysis cells fell below the detection limit at 10-15 $\mathrm{m}$ (Figure 4c). The highest adsorption of this toxin (3994 ng.g resin-week ${ }^{-1}$ ) was observed on 2 October, i.e., 7 days after the D. acuta maximum was observed. Although Dinophysis cells were no longer observed at 10-15 m after 3 October, OA was still found in the SPATT discs until the end of the study.

DTX2 (42-1634 $\mathrm{ng} \cdot \mathrm{g}$ resin-week ${ }^{-1}$ ) was first found in the $12 \mathrm{~m}$ SPATT discs on 4 September coinciding with a sustained increase of D. acuta. Maximum adsorption of DTX2 (1634 ng.g resin-week $\left.{ }^{-1}\right)$ on 2 October was 7 days after the seasonal maximum of D. acuta. Although D. acuta and D. caudata had fallen to undetectable levels since 24 October, DTX2 was tracked until 12 December.

PTX2 (5-2590 ng.g resin-week ${ }^{-1}$ ) maximal adsorption was observed on 2 October, 7 days after the peak value of $D$. acuta $\left(4640\right.$ cell $\left.\cdot \mathrm{L}^{-1}\right)$. Moderate levels of this toxin were found in the SPATT discs until the end of the study.

PTX2SA (32-1028 ng.disc $\left.{ }^{-1}\right)$ was significantly related $\left(r^{2}=0.65, p<0.001\right)$ with concentrations of PTX2 found at the same depth.

\subsection{Simulations of Toxin Adsorption by SPATT at $3 \mathrm{~m}, 7 \mathrm{~m}$ and $12 \mathrm{~m}$}

Simulation based on toxin content of picked cells of Dinophysis provided a good fit to the SPATT deployed at $12 \mathrm{~m}$, quite good fit to the SPATT at $3 \mathrm{~m}$, and for PTX2 to the SPATT at $7 \mathrm{~m}$. Fits for OA and DTX2 to the SPATT at $7 \mathrm{~m}$ were not so good, although the correlation between simulated and actual data was always statistically significant $(p<0.005)$ (Figure 5, Table 1$)$. Model concentrations of all toxins accumulated on the SPATT reached were very close to the actual data (Figure 5). In contrast most of the fits based on toxin per cell estimated from the size-fractioned plankton concentrates were not good, although they were statistically significant in most cases $(p<0.005)$ with the exception of the PTX2 toxin on the SPATT at $3 \mathrm{~m}$ and the OA on the SPATT at $12 \mathrm{~m}$. 
Figure 5. Simulated fits of toxin accumulation on the SPATT based on the average of toxin content (pg cell ${ }^{-1}$ ) per cell of Dinophysis estimated from analyses of picked cells of each species, to data of accumulation of (a) okadaic acid (OA) (b) dinophysistoxins (DTX2) (c) pectenotoxins (PTX2).
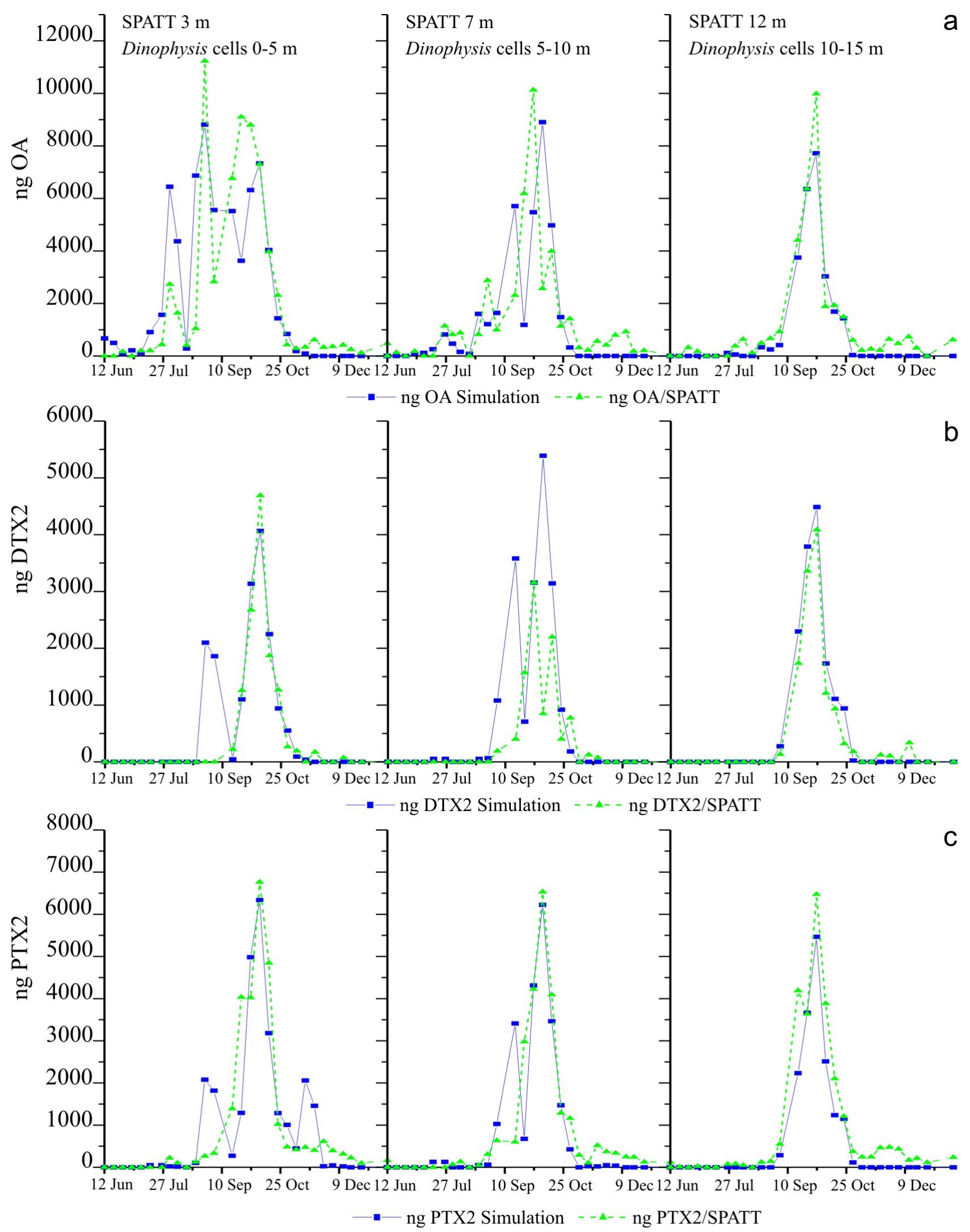
Table 1. Main parameters of the linear regressions between the actual data of toxins accumulated by SPATT and the simulation based on Dinophysis field concentrations $\left(\right.$ cell $\cdot \mathrm{L}^{-1}$ ) and their toxin content (pg cell ${ }^{-1}$ ) estimated from liquid chromatography-mass spectrometry (LC-MS) analyses of picked cells and pumped size-fractioned (77-20 $\mu \mathrm{m})$ plankton concentrates (plankton).

\begin{tabular}{cccccccc}
\hline \multirow{2}{*}{ Toxin } & $\begin{array}{c}\text { Source of toxin data } \\
\mathbf{( p g ~ c e l l ~}^{-\mathbf{1}} \text { ) }\end{array}$ & \multicolumn{2}{c}{ SPATT, 3 $\mathbf{~ m}$} & \multicolumn{2}{c}{ SPATT, 7 m } & \multicolumn{2}{c}{ SPATT, 12 m } \\
& $\boldsymbol{r}^{\mathbf{2}}$ & slope & $\boldsymbol{r}^{\mathbf{2}}$ & slope & $\boldsymbol{r}^{\mathbf{2}}$ & slope \\
\hline \multirow{2}{*}{ OA } & picked cells & 0.62 & 0.70 & 0.34 & 0.61 & 0.95 & 0.87 \\
& plankton & 0.44 & 1.74 & 0.07 & 1.35 & 0.68 & 1.96 \\
\multirow{2}{*}{ DTX2 } & picked cells & 0.74 & 0.90 & 0.39 & 1.18 & 0.98 & 1.14 \\
& plankton & 0.46 & 0.82 & 0.44 & 1.16 & 0.78 & 0.92 \\
\multirow{2}{*}{ PTX2 } & picked cells & 0.72 & 0.78 & 0.79 & 0.88 & 0.94 & 0.79 \\
& plankton & 0.19 & 1.13 & 0.65 & 1.70 & 0.90 & 1.75 \\
\hline
\end{tabular}

Concentrations of accumulated toxins in this case largely overestimated the real amounts found in the SPATT discs except in the case of DTX2, a toxin for which simulated and actual data were very close (Figure 6).

\section{Discussion}

\subsection{Seasonal and Annual Variability of the Toxin Profile and Content in Picked Cell of Dinophysis}

Knowledge on the toxin profile and content of Dinophysis species contributing to toxic outbreaks in a given region are essential parameters for predictive models on toxin uptake and depuration in shellfish. Nevertheless the toxic potential of each species may show considerable seasonal [9] and interannual variability and needs to be frequently evaluated. Table 2 compiles data on lipophilic toxin profile and content of Dinophysis cells from previous studies in the Galician Rías (Pontevedra and Vigo) in addition to the present study. All toxin analyses were performed by LC-MS under identical conditions to those mentioned in Sections 4.3 and 4.4 for the systematic sampling conducted during 2006. These results confirm the presence of only OA at detectable levels in the toxin profile of D. acuminata, and show important interannual differences. For example, the average toxin content of D. acuminata specimens isolated in 2006 was threefold that observed in those from 2005. OA, DTX2 and PTX2 were always observed in the toxin profile of $D$. acuta in the 23 samples analyzed during 2005 and 2006. The interannual differences in toxin content of this species were not as marked as in the case of $D$. acuminata. PTX2 was the dominant or even the only toxin present in the profile of D. caudata. This species showed considerable changes in both toxin profile (OA and/or DTX2 in addition to PTX2) and content. D. rotundata (=Phalacroma rotundatum) specimens were either non toxic, or exhibited a very low toxin content $\left(<1 \mathrm{pg}\right.$ cell $\left.^{-1}\right)$ with profiles common to those present in co-occuring species of Dinophysis. An earlier study [18] asked whether this heterotrophic species produces toxins de novo or just takes it up from its ciliate prey previously fed with toxic Dinophysis spp. 
Figure 6. Simulated fits of toxin accumulation on the SPATT, based on toxin content (pg cell ${ }^{-1}$ ) per cell of Dinophysis estimated from analyses of the size-fractioned $(77-20 \mu \mathrm{m})$ plankton concentrates, to the actual data of accumulation (a) OA (b) DTX2 (c) PTX2.
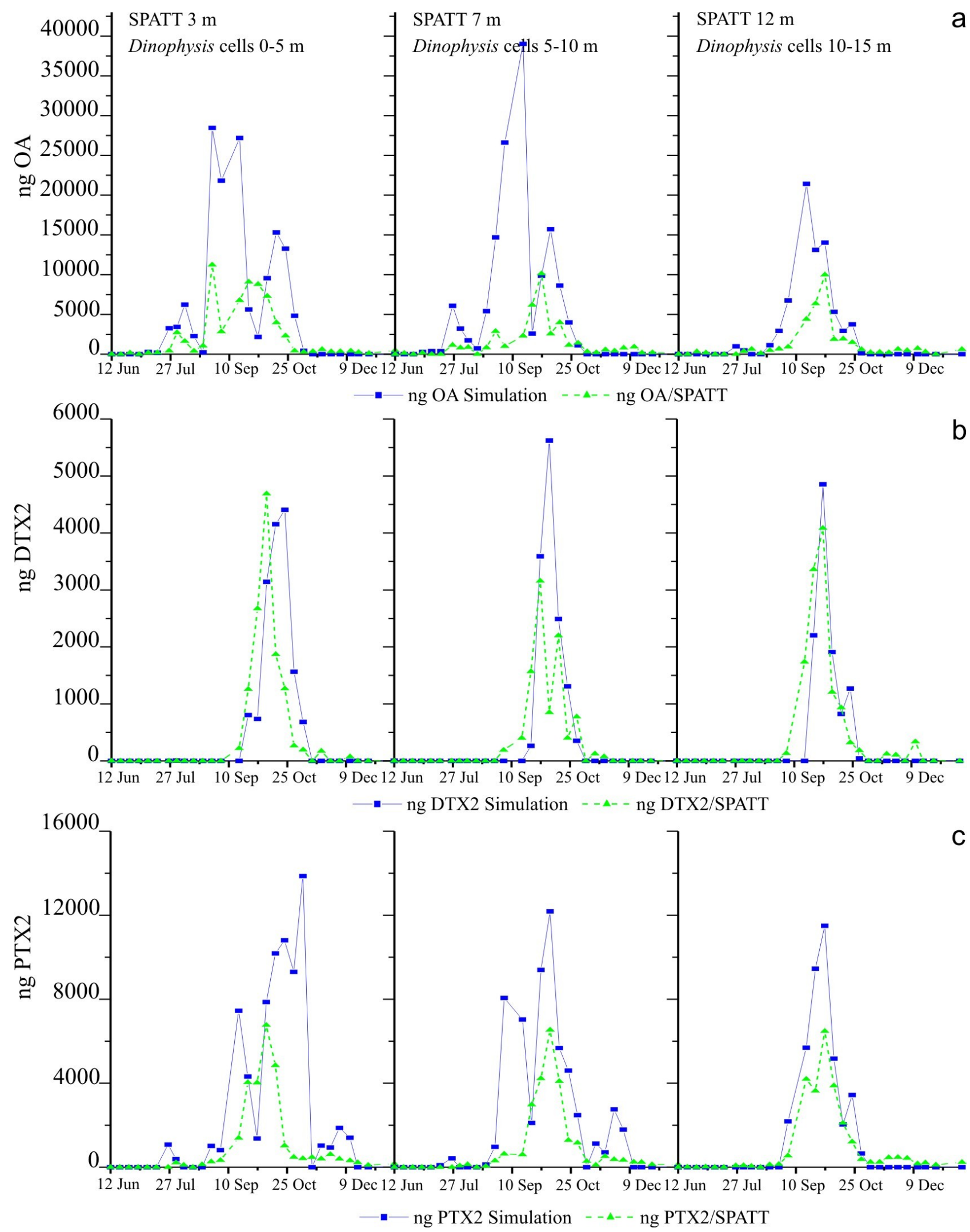
Table 2. Interannual variability of toxin content $\left(\mathrm{pg}\right.$ cell ${ }^{-1}$ ) in picked cells of different species of Dinophysis from Ría de Pontevedra (station P2) and Ría de Vigo (Stations D13, Moaña), NW Spain, analyzed with identical methods.

\begin{tabular}{|c|c|c|c|c|c|c|c|}
\hline \multicolumn{8}{|c|}{ Cellular toxin content $\left(\mathrm{pg}\right.$ cell $\left.^{-1}\right)$, mean $\pm \mathrm{SD}$} \\
\hline Dinophysis species & year & $\mathbf{O A}$ & DTX2 & PTX2 & $n$ & Location & Reference \\
\hline \multirow[t]{4}{*}{ D. acuminata } & 2002 & 12.1 & nd & nd & 1 & Bueu & [19] \\
\hline & 2003 & 1.0 & nd & nd & 1 & Bueu & [19] \\
\hline & 2005 & $1.3 \pm 1.0$ & nd & nd & 15 & Bueu & [19] \\
\hline & 2006 & $3.7 \pm 1.8$ & nd & nd & 8 & Bueu & this work \\
\hline D. skagii & 2006 & nd & nd & nd & 1 & Bueu & this work \\
\hline \multirow[t]{2}{*}{ D. acuta } & 2005 & $3.8 \pm 2.5$ & $3.7 \pm 2.4$ & $1.5 \pm 1.0$ & 11 & Bueu & [19] \\
\hline & 2006 & $2.9 \pm 2.0$ & $1.9 \pm 1.5$ & $2.8 \pm 2.7$ & 12 & Bueu & this work \\
\hline \multirow[t]{3}{*}{ D. caudata } & 2003 & nd & nd & $44.4 \pm 15.1$ & 2 & Bueu & [19] \\
\hline & 2005 & nd & nd & 3.9 & 1 & D13 & [19] \\
\hline & 2006 & 0.6 & 2.8 & 5.0 & 1 & Moaña & this work \\
\hline \multirow[t]{3}{*}{ D. rotundata } & 2003 & $0.2 \pm 0.2$ & nd & $0.3 \pm 0.4$ & 5 & Bueu & [18] \\
\hline & 2005 & $0.4 \pm 0.5$ & $0.5 \pm 0.6$ & nd & 2 & Bueu & [18] \\
\hline & 2007 & nd & nd & nd & 4 & Bueu & [18] \\
\hline
\end{tabular}

3.2. Simulations of Toxin Accumulation in the SPATT versus the Actual Observations: What Is the Source of the SPATT-Accumulated Toxins?

The goodness-of-fit, shown by the high percentage of the variance explained ( $40 \%$ to $98 \%$ ), and the slope of the regression (close to 1) confirm that simulations based on toxin content (pg cell ${ }^{-1}$ ) estimated from picked cells of each species of Dinophysis are much closer to the actual data than those obtained with estimates of toxin content per cell of Dinophysis in plankton concentrates (Table 2). In the last case, the percentage of the variance explained is much lower ( $7 \%$ to $90 \%)$ and the slope of the regression is always higher than one and in some cases closer to two. These results indicate that in most of the simulations using toxin content from plankton concentrates, the predicted accumulation in SPATT is almost double the observed value. This may indicate that in those situations, the toxin content per cell is grossly overestimated. This may be the case, for example, with the estimated toxin content of 180 pg PTX2 cell ${ }^{-1}$ from early November. We [9] proposed earlier that similar observations indicate that in plankton net-hauls collected in turbulent water-columns - rich in detritus and fecal pellets and with undetectable levels of Dinophysis - most of the toxins detected are those adsorbed by organic aggregates. This view is supported by the fact that accumulation of PTX2 in the resins (and presumably in mussels) decreased considerably from 30 October onwards, when the water column was well mixed.

Nevertheless, the use of a constant average value $\left(\mathrm{pg}\right.$ cell $^{-1}$ ) for the toxin content of Dinophysis cells has some inconveniences. We used this average because we could not obtain weekly estimates of toxin content for all the species. We know very little about the balance between production and release of toxins in field populations of Dinophysis, and it may well be that each toxin follows a different pattern of production and release in response to changing environmental conditions and their interaction with the physiological status of the population. In addition, we know already from culture 
experiments that toxin content per cell results from a balance between division rate (that dilutes toxin accumulation per cell) and toxin production rate, resulting in "more toxic" cells when division declines in stationary phases of the population [20-22]. For example, in this study, the tiny amount of DTX2 accumulated in the SPATT on 4 September following a peak $\left(3200\right.$ cell $\left.\cdot \mathrm{L}^{-1}\right)$ of $D$. acuta the previous week is intriguing. In this particular case, simulations based on toxin content in the plankton concentrates were closer to the actual accumulation of DTX2 (Figures 5 and 6). Unfortunately, no data is available on toxin per cell of D. acuta on these days because hardly any cells of this species were collected through the shallow (1-3 m) inflow depth of our pump system, although plenty of cells were detected in the $0-5 \mathrm{~m}$ and 5-10 $\mathrm{m}$ sections of the hose sampler (Figures 3 and 4). The use of vertical $(0-15 \mathrm{~m})$ net hauls as a source for picked cells would have solved this problem, but net hauls are a much "dirtier" material than size-fractioned pump concentrates, and picking of individual cells of Dinophysis is much harder with the former.

The mathematical equation used for the simulations in this work was based on that used in the model of Blanco [23] to simulate the accumulation of toxins by molluscan shellfish species. Nevertheless, the loss term of the equation was not included because there is no depuration of toxins on the SPATT, i.e., whatever is adsorbed remains accumulated in the discs. In this sense, SPATT cannot mimic the accumulation of toxins by mussels at a given time, because in these bivalves elimination of toxins starts at the very moment they are ingested, mainly in the feces [24]. Therefore, SPATT may accumulate a much higher amount of toxins than those a mussel would be able to during the same period of time. The good fits obtained for most of the toxins and depths where SPATT was deployed (with a model based on the cell density of Dinophysis and using a constant value for the toxin content per cell) indicates that what SPATT data basically reflect are variations in cell density and their toxin content, and probably more reliably than is obtained with discrete sampling. This is because SPATT is fixed and continuously exposed to the spatio-temporal variability in Dinophysis distributions, thus behaving as an artificial mussel that integrates results over time. The good fits with Dinophysis-borne toxins also suggest that variations in the percentage of particulate and dissolved toxins in the real world are not as large as those reported from cultures of D. acuminata [21,25], D. acuta [22] and of other dinoflagellates producers of lipophilic toxins, such as Protoceratium reticulatum and Lingulodinium polyedra [26,27].

An important question concerning the PTX2SA is whether the source of this toxin in the SPATT was transformed PTX2, either from broken cells of Dinophysis present in the water column or degradation within the SPATT resins themselves. If either option were the case, a lag between fits of the simulations for this toxin and those for OA and DTX2 should be observed, because part of the particulate PTX2 in Dinophysis cells would be converted into PTX2SA. Nevertheless the goodness-of-fit in the case of PTX2 simulations with toxin per picked cell data is much better than that for the OA and DTX2 simulations. These results suggest an alternative source for the accumulated PTX2 other than Dinophysis cells. Our hypothesis is that the source of PTX2SA accumulated in the SPATT is the release of PTX2SA contained in fecal pellets of mussels and copepods following ingestion of Dinophysis cells. Two facts support this hypothesis: (i) The location of our SPATT discs that were deployed on a rope contiguous to the mussel ropes of a mussel cultivation raft; (ii) the arrest of PTX2SA accumulation in the SPATT after 4 December when toxins in mussels dropped below regulatory levels, although OA and PTX2 were accumulated until the end of the study. 


\subsection{Assessment of the Use of SPATT as a Tool in Research and Monitoring of Lipophilic}

\section{Toxin Outbreaks}

Weekly monitoring of harmful algal bloom (HAB) species provides Dinophysis densities (from $0-5,5-10,10-15,15-20 \mathrm{~m})$ at a single station and time of day, but the diurnal vertical migration (DVM) of each species combined with short-term variability associated with the local wind-driven circulation and tides may lead to dramatic changes in vertical distribution on a scale of days (wind shifts) and hours (diurnal tidal cycle). In contrast, SPATT discs accumulate toxins from the previous 7 days and integrate vertical distribution variability. Therefore, we cannot always expect good correlations between toxins adsorbed by the resins and co-occurring Dinophysis densities. Integrated water column samples also integrate vertical discontinuities. A good example of these discrepancies between integrated versus single-depth samples [4] was the almost mono-specific bloom of D. ovum detected with the pumped size-fractioned plankton concentrate on 12 June, that in the $0-5 \mathrm{~m}$ hose sample co-occurred (50\% of each) with $D$. acuminata. The data show that a marked density gradient was formed at about $3 \mathrm{~m}$ depth on 12 June when the pump sample was collected, and D. ovum was probably aggregated in a thin layer just where the pump intake was cast (Figure 7). Preferential aggregation of $D$. ovum in near surface layers of the water column (where the pump samples were taken) would also explain the dominance of this species until late June in the plankton concentrates, whereas $D$. acuminata was dominant in the monitoring water column samples at $0-5 \mathrm{~m}$. These early peaks of $D$. ovum and $D$. acuminata did not lead to any accumulation of toxins in the SPATT at any depth. Either cells from early stages of the bloom did not release any toxins or they were forming very short-lasting thin layers embedded in a diatom-dominated microplankton community.

Figure 7. Vertical distribution of temperature $\left({ }^{\circ} \mathrm{C}\right)$, salinity (psu) and density (sigma-t) at the sampling station P2 on (a) 5 June (b) 12 June 2006. The asterisk marks the depth where the pump sample dominated by $D$. ovum was taken.
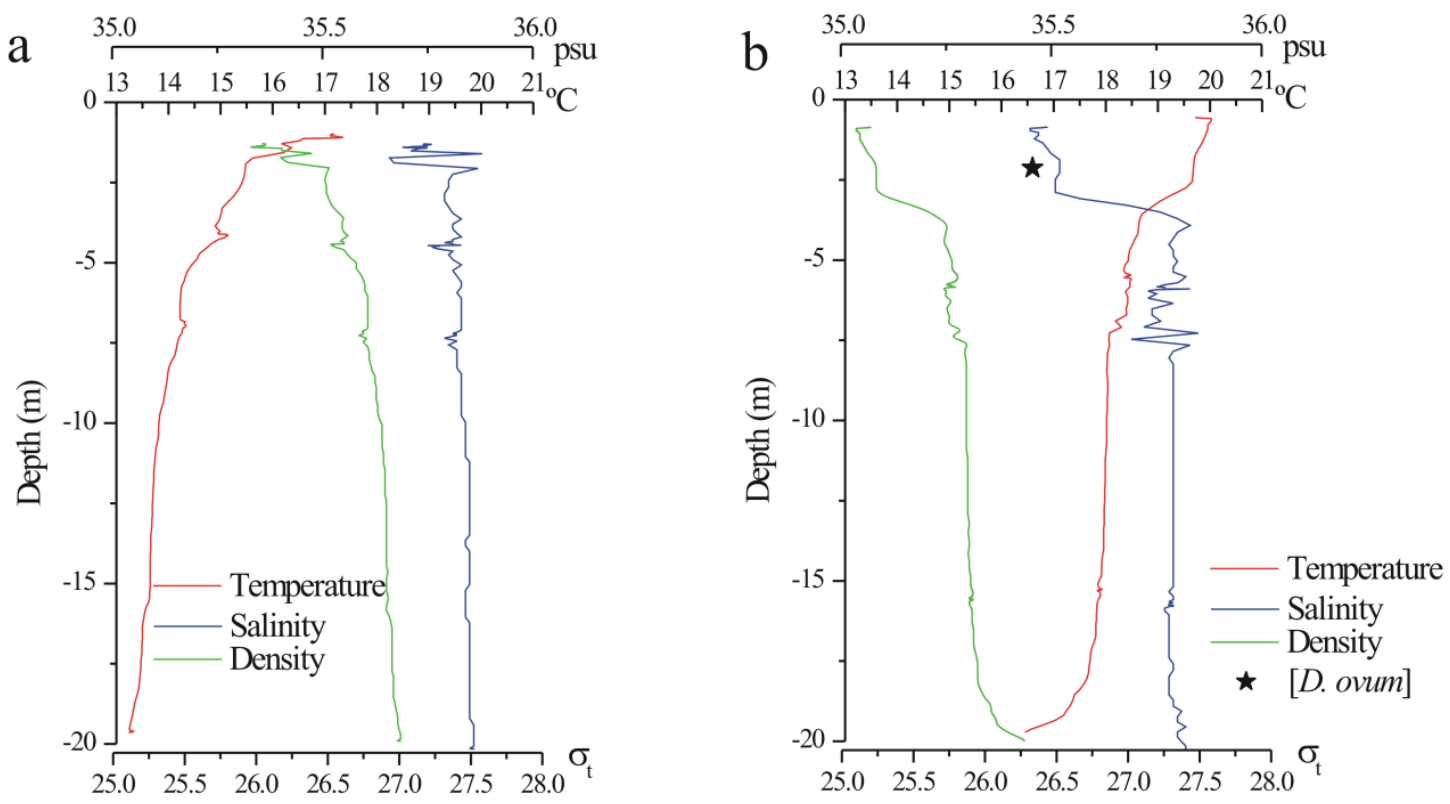
From earlier studies $[15,19,28]$ in addition to results presented here, all using the same analytical methods, the positive associations between the accumulation of $\mathrm{OA}$ and the peaks of D. acuminata and D. acuta, between DTX2 and the occurrence of D. acuta and between PTX2 and both, D. acuta and D. caudata in Galician coastal waters, seem clear.

The main question to be posed for phycotoxin monitoring programs is: Is the SPATT useful as an early warning tool for diarrhetic shellfish poisoning events? Figure 4a,b shows several examples where detection ( $\geq 40$ cell $\cdot \mathrm{L}^{-1}$ ) of Dinophysis cells took place well ahead (several weeks) of the detection of toxins in the resins. The first detection of OA in the SPATT was one week after the first seasonal increase of Dinophysis in surface waters (Figure 4a,b). Further, accumulation of toxins was maximal during late stages of the populations of different species of Dinophysis, suggesting that toxin-release is higher during late exponential, early stationary growth phases. Therefore, detection of Dinophysis cells, sampled with sufficient frequency (weekly at least) and spatial coverage provides the best early warning of the potential risk of future accumulation of toxins in shellfish above regulatory levels (RL). In the present study, detectable accumulation of OA in the SPATT discs took place 2-3 weeks before concentrations of this toxin in mussels - controlled by mouse bioassays (MBA) - was above RL. Nevertheless, in a control laboratory where lipophilic toxins are routinely monitored with LC-MS analyses of shellfish flesh, toxins in the SPATT would be detected more or less at the same time as in shellfish, as already found in Irish waters [29], or maybe a few days in advance, since accumulation in the resins is sometimes much higher than in shellfish. This is the case when high concentrations of total phytoplankton lead to decreased filtration rates in bivalves [30].

The amount of toxins adsorbed per week by the SPATT during the 2006 maximum of D. acuta in the present work was larger than those cited during blooms of the same species in New Zealand [11] and Ireland [12] and about double the maximum amount collected during the 2005 bloom in the same location the previous year [14]. Therefore, the use of SPATT allows an evaluation of the intensity of DSP outbreaks in different regions and of interannual variability in the same location.

Accumulation of toxins in the SPATT lasted more than 1.5 months after the end of shellfish harvesting closures in the case of OA and PTX2, but this was reduced to 1 week in the case of DTX2, a toxin that seems to be much less stable after its release in seawater. We could conclude that resins work as a more sensitive artificial mussel. But resins do not reflect enzymatic changes of the toxin profile that take place within the shellfish flesh. For example, mussels can transform all the ingested PTX2 into PTX2SA, and then be safe for human consumption, while the resins continue to detect PTX2 in the water column. Likewise, SPATT will in most cases overestimate the actual accumulation in shellfish because in bivalves we have to include fecal pellets as a loss factor (see the previous section). We can conclude that SPATT can be useful as a tool for early detection of initiation or advection of Dinophysis populations in areas not subject to toxin monitoring but that may represent a source of toxic cells to the aquaculture sites. In that case, they should be deployed in a wide range of depths including near the bottom and in the pycnocline. This kind of application has allowed detection of Dinophysis populations and/or their toxins in deep shelf waters in SW Ireland [31]. 


\section{Experimental Section}

\subsection{Field Sampling}

Weekly sampling was carried out during 2006, on board R/V Navaz, at a fixed station $\left(\mathrm{P} 2,42^{\circ} 21.40^{\prime} \mathrm{N}, 8^{\circ} 46.42^{\prime} \mathrm{W}\right)$ in Ría de Pontevedra (Figure 1), a hot spot for DSP outbreaks according to historic data from monitoring programs in the region. Phytoplankton samples for toxin analyses were collected from 5 June-when the presence of Dinophysis spp. started to be reported by the Galician monitoring centre (INTECMAR) (www.intecmar.es) - until 18 December 2006. Plankton 20-77 $\mu \mathrm{m}$ size-fractioned concentrates were obtained by pumping seawater with a submersible pump (flow of $138 \mathrm{~L} \mathrm{~min}^{-1}$ ) from a fixed depth in the top $5 \mathrm{~m}$ of the water column for 5-10 min, through a set of superimposed screens with meshes of decreasing size (100, 77 and $20 \mu \mathrm{m})$. The screens were set over a container with a drain-overflow located at the top, above the base level of the nets, so that the plankton concentrate was always kept submerged (Figure 8). This concentrate was re-suspended in 5-L bottles of seawater to keep the cells in healthy conditions until arrival at the laboratory (approximately $1 \mathrm{~h}$ ). A 50-mL subsample of this "pump-concentrate" was preserved with Lugol's iodine solution for cell identification and quantification. Density (cells $\cdot \mathrm{L}^{-1}$ ) and relative abundance of Dinophysis species in these pump-concentrates from the 3-5 $\mathrm{m}$ water layer were not expected to represent the population in the whole water column. They were obtained to collect enough cells of Dinophysis for toxin analyses (toxin profile and content) of individually picked cells of each species and of the total microplankton community.

Figure 8. Simplified diagram of the submersible pump and superimposed framed meshes system used to obtain the $77-20 \mu \mathrm{m}$ size-fractioned plankton concentrates.

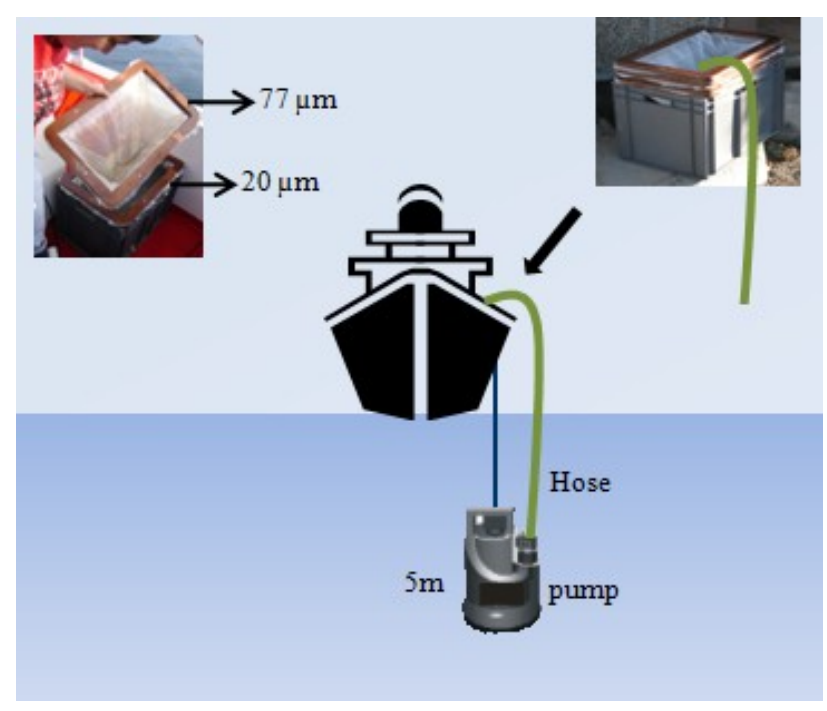

Simultaneously, integrated water column samples for plankton analyses were collected at the same station with a dividable hose sampler $(0-5,5-10,10-15 \mathrm{~m})$, as described by Lindahl [32], by the Galician Monitoring Centre (www.intecmar.org) and immediately fixed with Lugol's solution (Figure 9). 
Figure 9. Simplified diagram of a dividable tube (hose) sampler and sources of discrepancies between integrated water column (hose sampler [32]) and specific depth (oceanographic bottles) samples when phytoplankton cells are aggregated in thin layers (right). Reproduced with permission from [4], Copyright (C) 2012 Elsevier.

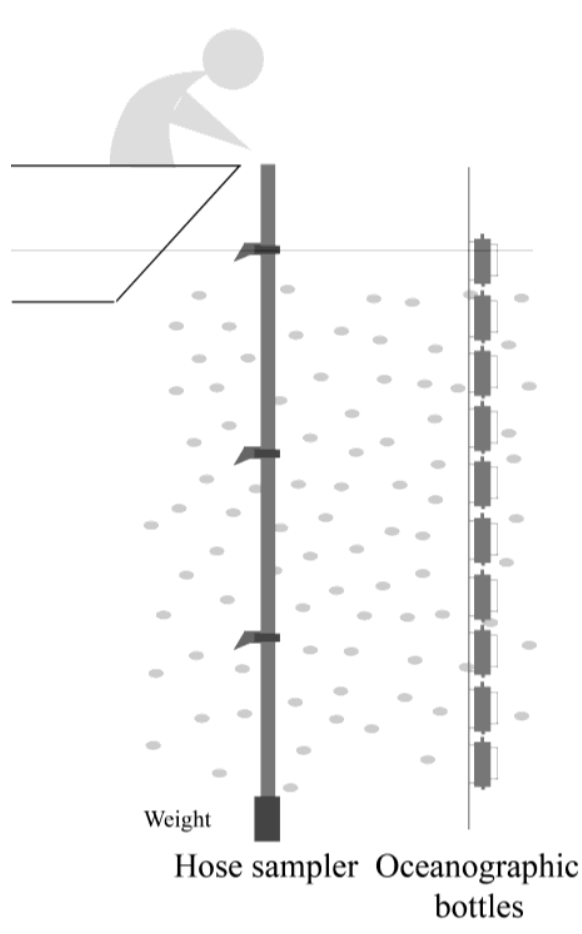

HOMOGENEOUS DISTRIBUTION

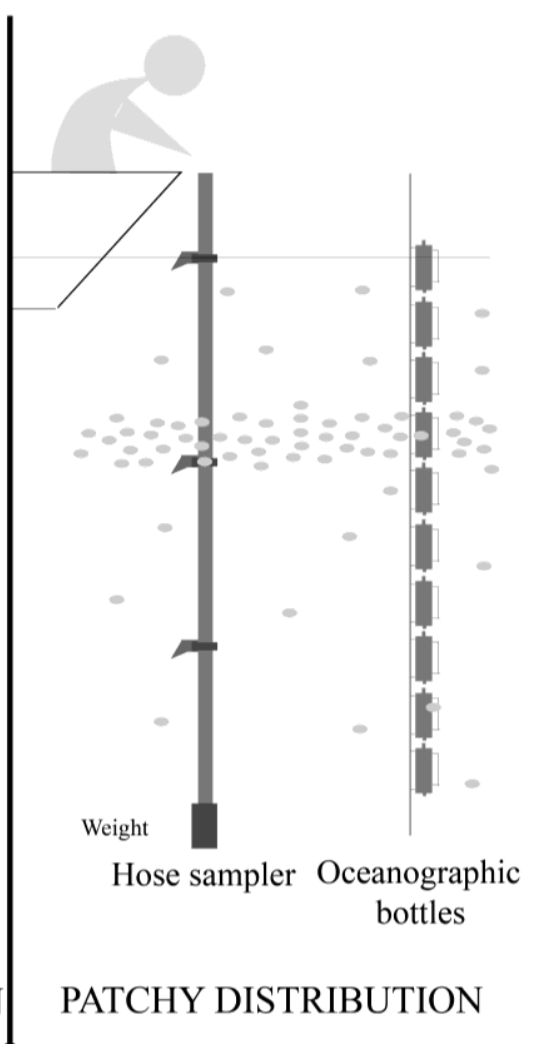

DIAION HP20 adsorbing resins filling the SPATT discs were used to track extracellular lipophilic toxins in the water column at 7-day intervals between 20 February and 18 December 2006. Activation was performed, as described in MacKenzie et al. [11] by leaving the DIAION HP20 resins (100 g) in contact with methanol $(1 \mathrm{~L})$ overnight, prior to filtration through a $23-\mu \mathrm{m}$ mesh, resuspension in $1 \mathrm{~L}$ of MQ water for $30 \mathrm{~min}$, drainage and storage in $1 \mathrm{~L}$ MilliQ water at $4{ }^{\circ} \mathrm{C}$ until use.

SPATT discs made with $77-\mu \mathrm{m}$ plankton mesh mounted on embroidery hoops (9-cm diameter), and filled with $25 \mathrm{~mL}$ of a suspension of resins in Milli-Q water (equivalent to $2.5 \mathrm{~g}$ dry weight of resin), were deployed at 3,7 and $12 \mathrm{~m}$ depth on a rope hung from a mussel raft. Each time, SPATT discs from the previous week were collected and replaced by new ones in the same positions. Care was taken that the resin-holders did not dry out before being placed in the water. The possibility of resin saturation in the field was discarded after testing in an earlier study [9].

\subsection{Phytoplankton Counts}

For identification and quantification of Dinophysis species and other potential toxin producers, aliquots of the Lugol-fixed pump-concentrate samples were placed in 3-mL HydroBios sedimentation chambers (Hydro-Bios Apparatebau GmbH, Kiel, Holtenau, Germany), left to settle for a few hours, and the whole surface of the chamber scanned at a magnification of $100 \times$ under a Nikon Eclipse TE2000-S inverted microscope (Nikon, Tokyo, Japan). To estimate toxin content per cell in the 
pump-concentrates, the total amount of toxins estimated from the $15 \mathrm{~mL}$ extract (see Section 3.3) was divided between the number of Dinophysis cells contained in that volume. Phytoplankton analyses at INTECMAR were carried out according to Utermöhl [33]. Aliquots of $25 \mathrm{~mL}$ of the $0-5 \mathrm{~m}, 5-10 \mathrm{~m}$, 10-15 $\mathrm{m}$ and 15-20 $\mathrm{m}$ integrated water column samples were left to sediment overnight. To enumerate large species, such as Dinophysis spp., the whole surface of the chamber was scanned at a magnification of $100 \times$ under the inverted microscope (detection level of $40 \mathrm{cell} \cdot \mathrm{L}^{-1}$ ).

\subsection{Toxin Extraction from Phytoplankton Pump-Concentrates, Picked Cells and SPATT Resins}

In the laboratory, $15 \mathrm{~mL}$ aliquots of the 20-77 $\mu \mathrm{m}$ fraction of phytoplankton concentrates were centrifuged for $20 \mathrm{~min}$ at $1000 \mathrm{rpm}$ and the supernatants eliminated; pellets were re-suspended in $500 \mu \mathrm{L}$ of methanol, the mixture sonicated for $1 \min (35-40 \mathrm{KHz})$ and the samples kept frozen until analysis. Just before analyses, samples were defrosted, centrifuged at $5000 \mathrm{rpm}$ for $20 \mathrm{~min}$, the supernatant collected, and the pellet re-suspended with $2 \mathrm{~mL}$ of methanol for a second extraction repeating the same procedure. The two supernatants were combined, mixed and methanol added to make up a final volume of $4 \mathrm{~mL}$. A $1.5-\mathrm{mL}$ aliquot of this solution was dried at $40{ }^{\circ} \mathrm{C}$ under reduced pressure on a Speed Vac (Savant, Instruments Inc., Holbrook, NY, USA), re-suspended in $150 \mu \mathrm{L}$ of methanol and filtered through $0.45-\mu \mathrm{m}$ filters (13-mm Gelman Nylon Acrodisc, Albany, NY, USA or 3-mm Osmonic Inc., Cameo 3N, Minnetonka, MN, USA) prior to injection into the LC-MS system.

Dinophysis cells were individually picked from the 20-77 $\mu \mathrm{m}$ fraction of plankton concentrates with a microcapillary pipette under the inverted microscope $(40 \times$ and $100 \times)$, and passed two to three times through filtered $(0.22 \mu \mathrm{m})$ seawater. Between 30 and 100 cells of each species were transferred to $1.5-\mathrm{mL}$ Eppendorf tubes filled with $250 \mu \mathrm{L} \mathrm{mL}$ of Tris- $\mathrm{HCl}$ buffer $(50 \mathrm{mM}, \mathrm{pH} 7.4) ; 250 \mu \mathrm{L}$ of methanol were added and the mixture sonicated for $1 \mathrm{~min}$. The final extract-samples - kept in the deep freezer until analysis - were transferred to vials of $1.8 \mathrm{~mL}$, the remains in the Eppendorf tube washed with $500 \mu \mathrm{L}$ of methanol and the supernatants combined and mixed. This solution was dried and processed in the same way as those obtained from plankton-concentrates.

Extraction of toxins from the SPATT discs was carried out following Pizarro et al. [14]. Briefly, after 7 days of exposure, SPATT discs were recovered and the resins washed with Milli-Q water $(40 \mathrm{~mL})$ to eliminate sea salts. After drainage, the resin was soaked with $20 \mathrm{~mL}$ of methanol and left a minimum of $2 \mathrm{~h}$ before elution of the methanol. The resin was then washed five times with $10 \mathrm{~mL}$ of methanol (flow of $0.5 \mathrm{~mL} \mathrm{~min}{ }^{-1}$ ) until a final volume of $50 \mathrm{~mL}$ was reached. These pre-extraction samples were kept below $4{ }^{\circ} \mathrm{C}$ until analysis. To prepare for the LC-MS analysis, $4 \mathrm{~mL}$ of the extract were dried at $40{ }^{\circ} \mathrm{C}$ under reduced pressure on a vacuum concentrator (Speed Vac), resuspended in $500 \mu \mathrm{L}$ of methanol and filtered through $0.45-\mu \mathrm{m}$ filters prior to injection into the LC-MS system.

\subsection{LC-MS Analyses}

LC-MS analyses were performed on a Thermo Finnigan Surveyor coupled to an ion-trap mass spectrometer (Thermo Finnigan LCQ-Advantage) equipped with a micro-electrospray ionization interface $(\mu \mathrm{ESI})$. Separations were achieved on a Waters XBridge C18 5- $\mu \mathrm{m}(2.1 \times 150 \mathrm{~mm})$ column at $35{ }^{\circ} \mathrm{C}$. The mobile phase consisted of $2 \mathrm{mM}$ ammonium acetate at $\mathrm{pH} 5.8$ (A) and methanol (B). A linear gradient elution of $60 \%-100 \% \mathrm{~B}$ for $20 \mathrm{~min}$ followed by $100 \% \mathrm{~B}$ for $2 \mathrm{~min}$ and 
re-equilibration with $60 \% \mathrm{~B}$ for $8 \mathrm{~min}$ was used. The flow rate was $0.2 \mathrm{~mL} \mathrm{~min}^{-1}$. The sample injection volume was variable $(5-20 \mu \mathrm{L})$ depending on the toxin concentration in the sample. $\mu$ ESI was performed at a capillary temperature of $250{ }^{\circ} \mathrm{C}$ and a spray voltage of 3.0 and $4.5 \mathrm{kV}$ for positive and negative analyses, respectively. Flows of $20 \mathrm{~mL} \mathrm{~min}^{-1}$ for sheath gas and of $10 \mathrm{~mL} \mathrm{~min}^{-1}$ for auxiliary gas were used. Full scan data were acquired from $\mathrm{m} / \mathrm{z} 300$ to 2000, in both negative and positive ionization modes. Identification of the toxins OA, DTX2, PTX2 and PTX2 SA was performed by LC-MS/MS in an earlier work by applying a supplementary voltage (Collision Energy, CE) of $60 \mathrm{eV}$ on the precursor ions at $m / z\left[\mathrm{M}+\mathrm{NH}_{4}\right]^{+}$[9]. Once these toxins were identified, routine analyses were performed by LC-MS for the sake of cost and rapidity of the analyses. The LC-MS analyses were carried out using the ions at $m / z 805[\mathrm{M}+\mathrm{H}]^{+}, 822\left[\mathrm{M}+\mathrm{NH}_{4}\right]^{+}, 827[\mathrm{M}+\mathrm{Na}]^{+}$and $803[\mathrm{M}-\mathrm{H}]^{-}$for $\mathrm{OA}$ and DTX2; $876\left[\mathrm{M}+\mathrm{NH}_{4}\right]^{+}, 881[\mathrm{M}+\mathrm{Na}]^{+}, 857[\mathrm{M}-\mathrm{H}]^{-}$and $918\left[\mathrm{M}+\mathrm{CH}_{3} \mathrm{COO}\right]^{-}$for PTX2; $894\left[\mathrm{M}+\mathrm{NH}_{4}\right]^{+}, 899[\mathrm{M}+\mathrm{Na}]^{+}$and $875[\mathrm{M}-\mathrm{H}]^{-}$for PTX2SA. Predominant ions were detected in positive mode for OA, DTX2, PTX2 and PTX2SA. Negative mode was performed only to confirm the toxin spectrum.

In the case of picked cells, to obtain a discernible signal according to the possibilities of the mass spectrometer, a single ion monitoring (SIM) analysis and positive ionization mode alone were used to record signals of the $\left[\mathrm{M}+\mathrm{NH}_{4}\right]^{+}$and $[\mathrm{M}+\mathrm{Na}]^{+}$ions for OA, DTX2 and PTX2. The presence of PTX2SA - considered an enzymatic transformation of PTX2 due to poor handling of plankton samples - was not explored as it has never been detected in phytoplankton samples in previous studies in the region $[9,14]$.

For the analyses of plankton concentrates and SPATT extracts, working solutions of OA, DTX2 and PTX2 - $0.6 \mathrm{ng} \mu \mathrm{L}^{-1}$ approximately, detection limit (DL) $6 \mathrm{ng} \mu \mathrm{L}^{-1}$ - and PTX2SA- $0.3 \mathrm{ng} \mu \mathrm{L}^{-1}$ approximately, DL $3 \mathrm{ng} \mu \mathrm{L}^{-1}$ — were used to generate a four-point calibration curve with variable injection volumes. Concentration ranges for the calibration lines obtained for each toxin were from 1.5 to $6.0 \mathrm{ng}$ for OA and DTX2, from 1.8 to $7.0 \mathrm{ng}$ for PTX2 and from 0.5 to $3.0 \mathrm{ng}$ for PTX2SA. For picked cells, a working solution of OA and DTX2-4 pg $\mu \mathrm{L}^{-1}$ approximately, DL $40 \mathrm{pg} \mu \mathrm{L}^{-1}$ —was used from 8 to $40 \mathrm{pg}$. A four-point calibration curve was generated with variable injection volumes. The linearity of each point was tested following van Trijp and Roos [34]. Full details of the LC-MS chromatograms and mass spectra in positive ionization mode are given in Pizarro et al. [9].

\subsection{Simulation of Toxins Adsorption by the SPATT Discs}

The adsorption of each type of toxin (OA, DTX2, PTX2) by the SPATT resins was mathematically simulated considering that SPATT at each depth behaved as an artificial mussel-with an adsorption rate of $3 \mathrm{~L} \mathrm{~h}^{-1}$ - which accumulated all the particulate toxins available in the filtered seawater following the equation:

$$
d T a / d t=C_{\text {cell }} C_{\text {tox }} F_{\text {ads }}
$$

where $T a$ is the amount of toxin adsorbed by the SPATT; $C_{\text {cell }}$ is the Dinophysis cell concentration per liter of seawater; $C_{\text {tox }}$ is the pg of toxin per cell of Dinophysis and $F_{\text {ads }}$ is the rate of toxin adsorption by the SPATT that was given a constant value of $3 \mathrm{~L} \mathrm{~h}^{-1}$. 
Two kinds of simulations were made for each type of toxin (OA, DTX2, PTX2) and depth (3 m, $7 \mathrm{~m}, 12 \mathrm{~m}$ ) of SPATT deployment: (i) one simulation that used the average estimate of toxin content (pg cell ${ }^{-1}$ ) per cell, for each species of Dinophysis used in the model, from the analyses of picked cells; (ii) another simulation that used the estimate of toxin content (pg cell ${ }^{-1}$ ) per cell of Dinophysis (daily interpolation between two consecutive weekly values) obtained from the analyses of the size-fractioned $(77-20 \mu \mathrm{m})$ plankton concentrates.

Data of Dinophysis cells per liter were interpolated daily between two consecutive weekly values. Dinophysis species included in the simulations for each kind of toxin were: (i) Dinophysis acuminata + Dinophysis acuta for OA; (ii) Dinophysis acuta for DTX2 and (iii) Dinophysis acuta + Dinophysis caudata for PTX2.

\section{Conclusions}

A systematic monitoring of HABs and lipophilic toxins (LC-MS) in picked cells of Dinophysis and in plankton concentrates led to confirmation of D. acuminata and D. acuta as the main sources of OA in Galician shellfish, D. acuta of DTX2 and both D. acuta and D. caudata of PTX2. Discrepancies between toxin per cell estimates and those from plankton concentrates suggest increased amounts of released toxins in the water during late stages of the bloom, which are attached to organic aggregates retained in the filters and not taken up by mussels. Likewise, discrepancies between toxins in plankton concentrates and those accumulated by the SPATT suggest zooplankton and shellfish faecal pellets as the source of PTX2SA in the resins. Model simulations showed best-fit between weekly toxin accumulation by the SPATT discs and the toxin content of Dinophysis cells per volume of water, estimated from a constant value of toxin content for each species, averaged from LC-MS analyses of picked cells. OA and PTX2 can persist "dissolved" in the water for weeks but DTX2 is less stable. Monitoring of Dinophysis cells with appropriate spatial (integrated samples) and temporal frequency provides earlier warning of DSP outbreaks than SPATT resins, which allow detection of toxins with a similar timing than that of detection in shellfish tissues by LC-MS analyses in regulatory centers. In addition, SPATT accumulation of toxins overestimates that taking place in shellfish and subject to loss terms (enzymatic transformation, fecal pellet elimination); further, SPATT continues accumulating toxins for weeks after Dinophysis cells become undetectable and mussels are depurated. SPATT provides a valuable tool for the study of Dinophysis population and their toxin dynamics, in particular if deployed in areas and depths not subject to regular surveillance. Further, it has the potential to be a relatively simple method which may provide a more efficient regulatory action, cost-savings, enhanced environmental toxin detection and a monitoring perspective that is less susceptible to the variability of discrete phytoplankton and shellfish sample collections. However, SPATT does not represent a practical gain for early warning of DSP outbreaks in aquaculture sites subject to routine monitoring of HABs and phycotoxins and for the time being should remain as a complementary tool to traditional sampling.

\section{Acknowledgments}

We are grateful to the crew of RV “J. M. Navaz" for their helpful attitude, to Pilar Rial, Isabel Ramilo and Amelia Fernández-Villamarín for technical assistance, and to the Galician 
Monitoring Program (www.intecmar.org) for continuous supply of information on phytoplankton and phycotoxins in the Galician Rías. This research was supported by projects "Dinophysis Galicia" (CTM2004-0478-CO3-01) and ASIMUTH (EU 7FP, SPACE, Grant Agreement \# 261860). G. Pizarro was funded by a Chilean pre-doctoral fellowship from the Centro de Estudios del Quaternario Fuego-Patagonia y Antartica (CEQUA) Foundation and the Instituto de Fomento Pesquero (IFOP). This is a contribution to the GEOHAB-Core Research Project HABs in Fjords and Coastal Embayments.

\section{Conflicts of Interest}

The authors declare no conflict of interest.

\section{References}

1. Yasumoto, T.; Murata, M.; Oshima, Y.; Sano, M.; Matsumoto, G.; Clardy, J. Diarrhetic shellfish toxins. Tetrahedron 1985, 41, 1019-1025.

2. Blanco, J.; Moroño, A.; Pazos, Y.; Maneiro, J.; Mariño, J. Trends and Variations of the Abundance of Main PSP and DSP Producing Species in the Galician Rías: Environmental and Biological Influences. In Harmful Algae; Reguera, B., Blanco, J., Fernández, M.L., Wyatt, T., Eds.; Xunta de Galicia and Intergovernmental Oceanographic Commission of UNESCO: Santiago de Compostela, Spain, 1998; pp. 204-207.

3. Farrell, H.; Gentien, P.; Fernand, L.; Lunven, M.; Reguera, B.; González-Gil, S.; Raine, R. Scales characterising a high density thin layer of Dinophysis acuta Ehrenberg and its transport within a coastal jet. Harmful Algae 2012, 15, 36-46.

4. Escalera, L.; Pazos, Y.; Doval, M.D.; Reguera, B. A comparison of integrated and discrete depth sampling for monitoring Dinophysis. Mar. Pollut. Bull. 2012, 64, 106-113.

5. Regulation (EC) No. 853/2004 of the European Parliament and of the Council of 29 April 2004. Off. J. Eur. Union 2004, L139, 55-205.

6. Reguera, B.; Pizarro, G. Planktonic Dinoflagellates which Produce Polyether Toxins of the Old "DSP Complex". In Seafood and Freshwater Toxins: Pharmacology, Physiology and Detection, 2nd ed.; Botana, L.M., Ed.; Taylor \& Francis: London, UK, 2008; pp. 257-284.

7. Reguera, B.; Velo-Suárez, L.; Raine, R.; Park, M.G. Harmful Dinophysis species: A review. Harmful Algae 2012, 14, 87-106.

8. Fux, E.; Smith, J.L.; Tong, M.; Guzmán, L.; Anderson, D.M. Toxin profiles of five geographical isolates of Dinophysis spp. from North and South America. Toxicon 2011, 57, 275-287.

9. Pizarro, G.; Paz, B.; González-Gil, S.; Franco, J.M.; Reguera, B. Seasonal variability of lipophilic toxins during a Dinophysis acuta bloom in Western Iberia: Differences between picked cells and plankton concentrates. Harmful Algae 2009, 8, 926-937.

10. Lindahl, O.; Lundve, B.; Johansen, M. Toxicity of Dinophysis spp. in relation to population density and environmental conditions on the Swedish west coast. Harmful Algae 2007, 6, 218-231.

11. MacKenzie, L.; Beuzenberg, V.; Holland, P.; McNabb, P.; Selwood, A. Solid phase adsorption toxin tracking (SPATT): A new monitoring tool that simulates the biotoxin contamination of filter feeding bivalves. Toxicon 2004, 44, 901-918. 
12. Fux, E.; Marcaillou, C.; Mondeguer, F.; Bire, R.; Hess, P. Field and mesocosm trials on passive sampling for the study of adsorption and desorption behaviour of lipophilic toxins with a focus on OA and DTX1. Harmful Algae 2008, 7, 574-583.

13. Lacaze, J.P. Solid-phase adsorption passive sampling: Review of a monitoring tool tracking in situ marine and freshwater toxins. In New Trends in Marine and Freshwater Toxins: Food and Safety Concerns; Cabado, A.G., Vieites, J.M., Eds.; Nova Science Publishers, Inc.: New York, NY, USA, 2012; pp. 91-113.

14. Pizarro, G.; Escalera, L.; González-Gil, S.; Franco, J.M.; Reguera, B. Growth, behavior and cell toxin quota of Dinophysis acuta Ehrenberg during a daily cycle. Mar. Ecol. Prog. Ser. 2008, 353, 89-105.

15. Raho, N.; Pizarro, G.; Escalera, L.; Reguera, B.; Marín, I. Morphology, toxin composition and molecular analysis of Dinophysis ovum Schutt, a dinoflagellate of the "Dinophysis acuminata complex". Harmful Algae 2008, 7, 839-848.

16. Miles, C.O.; Wilkins, A.L.; Munday, R.; Dines, M.H.; Hawkes, A.D.; Briggs, L.R.; Sandvik, M.; Jensen, D.J.; Cooney, J.M.; Holland, P.T.; et al. Isolation of pectenotoxin-2 from Dinophysis acuta and its conversion to pectenotoxin-2 seco acid, and preliminary assessment of their acute toxicities. Toxicon 2004, 43, 1-9.

17. Suzuki, T.; Mackenzie, L.; Stirling, D.; Adamson, J. Pectenotoxin-2 seco acid: A toxin converted from pectenotoxin-2 by the New Zealand Greenshell mussel, Perna canaliculus. Toxicon 2001, 39, 507-514.

18. González-Gil, S.; Pizarro, G.; Paz, B.; Velo-Suárez, L.; Reguera, B. Considerations on the toxigenic nature and prey sources of Phalacroma rotundatum. Aquat. Microb. Ecol. 2011, 64, 197-203.

19. Pizarro, G. Estudio, Mediante LC-MS, de la Variabilidad del Perfil y Contenido de Toxinas en Poblaciones de Dinophysis spp. Agentes de Episodios DSP en las Rías Baixas Gallegas. Ph.D. Thesis, University of Vigo, Vigo, Spain, 29 April 2008.

20. Tong, M.M.; Kulis, D.M.; Fux, E.; Smith, J.L.; Hess, P.; Zhou, Q.X.; Anderson, D.M. The effects of growth phase and light intensity on toxin production by Dinophysis acuminata from the northeastern United States. Harmful Algae 2011, 10, 254-264.

21. Nielsen, L.T.; Krock, B.; Hansen, P.J. Effects of light and food availability on toxin production, growth and photosynthesis in Dinophysis acuminata. Mar. Ecol. Prog. Ser. 2012, 471, 37-50.

22. Nielsen, L.T.; Krock, B.; Hansen, P.J. Production and excretion of okadaic acid, pectenotoxin-2 and a novel dinophysistoxin from the DSP-causing marine dinoflagellate Dinophysis acuta-Effects of light, food availability and growth phase. Harmful Algae 2013, 23, 34-45.

23. Blanco, J. Modelling as a Mitigation Strategy for Harmful Algal Blooms. In Shellfish Safety and Quality; Shumway, S.E., Rodrick, G.E., Eds.; Series in Food Science, Technology and Nutrition 167; Woodhead Publishing Ltd.: Cambridge, UK, 2009; pp. 200-227.

24. Rossignoli, A.E. Acumulación de Toxinas DSP en el mejillón Mytilus galloprovincialis. Ph.D. Thesis, University of Santiago de Compostela, Santiago de Compostela, Spain, 18 July 2011.

25. Smith, J.L.; Tong, M.; Fux, E.; Anderson, D.M. Toxin production, retention, and extracellular release by Dinophysis acuminata during extended stationary phase and culture decline. Harmful Algae 2012, 19, 125-132. 
26. Paz, B.; Riobó, P.; Fernández, M.L.; Fraga, S.; Franco, J.M. Production and release of yessotoxins by the dinoflagellates Protoceratium reticulatum and Lingulodinium polyedrum in culture. Toxicon 2004, 44, 251-258.

27. Paz, B.; Vázquez, J.A.; Riobó, P.; Franco, J.M. Study of the effect of temperature, irradiance and salinity on growth and yessotoxin production by the dinoflagellate Protoceratium reticulatum in culture by using a kinetic and factorial approach. Mar. Environ. Res. 2006, 62, 286-300.

28. Fernández, M.L.; Reguera, B.; González-Gil, S.; Míguez, A. Pectenotoxin-2 in single-cell isolates of Dinophysis caudata and Dinophysis acuta from the Galician Rías (NW Spain). Toxicon 2006, 48, 477-490.

29. Fux, E.; Bire, R.; Hess, P. Comparative accumulation and composition of lipophilic marine biotoxins in passive samplers and in mussels ( $M$. edulis) on the West Coast of Ireland. Harmful Algae 2009, 8, 523-537.

30. Moroño, A.; Arévalo, F.; Fernández, M.L.; Maneiro, J.; Pazos, Y.; Salgado, C.; Blanco, J. Accumulation and transformation of DSP toxins in mussels Mytilus galloprovincialis during a toxic episode caused by Dinophysis acuminata. Aquat. Toxicol. 2003, 62, 269-280.

31. Fux, E.; Gonzalez-Gil, S.; Lunven, M.; Gentien, P.; Hess, P. Production of diarrhetic shellfish poisoning toxins and pectenotoxins at depths within and below the euphotic zone. Toxicon 2010, $56,1487-1496$.

32. Lindahl, O. A dividable hose for phytoplankton sampling. In ICES Report of the Working Group on Exceptional Algal Blooms; ICES C.M. 1986/L:26, Annex 3; International Council for the Exploration of the Sea: Copenhagen, Denmark, 1986; pp. 1-3.

33. Utermöhl, H. Neue wege in der quantitativen Erfassung des Planktons (mit besonderer Berücksichtigung des Ultraplanktons). Verh. Int. Ver. Theor. Angew. Limnol. 1931, 5, 567-596.

34. Van Trijp, J.M.P.; Roos, A.H. Model for the Calculation of Calibration Curves; RIKILT Report 91.02; RIKILT-DLO: Wageningen, The Netherlands, 1991; pp. 1-4.

(C) 2013 by the authors; licensee MDPI, Basel, Switzerland. This article is an open access article distributed under the terms and conditions of the Creative Commons Attribution license (http://creativecommons.org/licenses/by/3.0/). 